\title{
COMPARISON OF METHYLENE BLUE ADSORPTION FROM AQUEOUS SOLUTION USING SPENT TEA DUST AND RAW COIR PITH
}

\author{
RAMESH S.T. \\ GANDHIMATHI R.* \\ ELAVARASI T.E. \\ ISAI THAMIZH R. \\ SOWMYA K. \\ NIDHEESH P.V.
}

\author{
Department of Civil Engineering \\ National Institute of Technology \\ Tiruchirappalli - 620015 \\ Tamilnadu, India
}

Received: 02/10/2013

Accepted: 03/12/2013

*to whom all correspondence should be addressed: e-mail: rgmathii@nitt.edu

\begin{abstract}
The purpose of the present work is to test the possibility of using the spent tea dust and raw coir pith for the removal of methylene blue (MB) from aqueous solution. The effects of the contact time, adsorbent dosage and solution $\mathrm{pH}$ were studied in batch experiments at $27^{\circ} \mathrm{C}$. Results showed that a pH of 7 is favourable for the adsorption of dye. The isothermal data could be well described by the Langmuir equations. Kinetic parameters of adsorption such as the Langergen pseudo-first-order, pseudo-second-order rate constant and the intraparticle diffusion rate constant were determined. The adsorption capacities of Spent Tea Dust (STD) and Raw Coir Pith (RCP) were found to be $86.21 \mathrm{mg}$ and $142.86 \mathrm{mg} \mathrm{g}^{-1}$ of the adsorbent respectively. The results indicate that STD and RCP could be employed as low-cost alternatives to commercial activated carbon for the removal of dyes from aqueous solution.
\end{abstract}

KEYWORDS: Adsorption; isotherm; Kinetics; Methylene blue; Spent tea dust; Raw coir pith.

\section{INTRODUCTION}

Many industries, such as dyestuffs, textile, paper and plastics, use dyes in order to color their products and also consume substantial volumes of water. As a result, they generate a considerable amount of colored wastewater. It is recognized that public perception of water quality is greatly influenced by the color. Color is the first contaminant to be recognized in wastewater (Banat et al., 1996). The presence of very small amounts of dyes in water (less than $1 \mathrm{ppm}$ for some dyes) is highly visible and undesirable (Robinson et al., 2001; Banat et al., 1996). Over 100,000 commercially available dyes exist and more than $7 \times 10^{5}$ tonnes per year are produced annually (Pearce et al., 2003). Due to their good solubility, synthetic dyes are common water pollutants and they may frequently be found in trace quantities in industrial wastewater. An indication of the scale of the problem is given by the fact that two percent of dyes that are produced are discharged directly in aqueous effluent (Robinson et al., 2001; Pearce et al., 2003). There are many structural varieties of dyes, such as acidic, basic, disperse, azo, diazo, anthroquinone based and metal complex dyes.

Basic dyes are widely used in acrylic, nylon, silk, and wool dyeing. Most of these dyes are toxic, mutagenic and carcinogenic (Eren and Acar, 2006, Nidheesh et al., 2013). Therefore, their removal from industrial effluents before discharging into the environment is extremely important (O'Neill et al., 1999; Hameed and El-Khaiary, 2008). Many treatment methods have been developed to remove dyes from wastewater. These treatment methods can be divided into physical, chemical and biological schemes. These include: adsorption (Nidheesh et al., 2011; Gandhimathi et al., 2012), coagulation (Ellouze et al., 2011), photo-electro-catalytic methods (Khataee and Zarei, 2011), electrocogulation (Rajabi et al., 2011), membrane (Srivastava et al., 2011) and photo catalysis (Lodha et al., 2011). Although chemical and biological approaches are effective in removing dyes, they require special equipment and are usually energy intensive; additionally, these processes often 
generate large amounts of byproducts (Zareyee et al., 2012). As synthetic dyes in wastewater cannot be efficiently decolorized by traditional methods, the adsorption of synthetic dyes on inexpensive and an efficient solid support was considered as a simple and economical method for their removal from water and wastewater (Forgacs et al., 2004).

$\mathrm{MB}$ is also an important basic dye widely used for printing calico, dyeing, printing cotton and tannin and dyeing leather. Although not strongly hazardous, MB can have various harmful effects. The dye can cause eye burns, which may be responsible for permanent injury to the eyes of human and animals, irritation to the gastrointestinal tract with symptoms of nausea, vomiting and diarrhea and also cause methemoglobinemia, cyanosis, convulsions, tachycardia, and dyspnea. Contact of MB with skin causes irritation (Hamdaoui and Chiha, 2007). The studies on MB adsorption onto coir pith (Namasivayam et al., 2001), activated carbon (Shaobin et al., 2005), rice husk (Vadivelan and Vasanth Kumar, 2005), peanut hull (Renmin et al., 2005) $\mathrm{KOH}$-activated and steam-activated carbons (Wu et al., 2005), pumice powder (Feryal, 2005), glass fibers (Sampa and Binay, 2005), coir pith carbon (Kavitha and Namasivayam, 2007), Pumpkin seed hull (Hameed and El-Khaiary, 2008), beer brewery waste (Tsai et al., 2008) have been reported.

Tea is basically the dried and processed leaves of only one specieshaobin of plant called Camellia sinensis (Mokgalaka et al., 2004). It is consumed by the largest number of people in the world and considered the second most popular beverage in the world. Canned or bottled tea drinks as well as instant tea drinks are produced on industrial scale by hot water extraction of tea leaves, and the producers face a problem in disposing of the spent tea leaves after the extraction. Agro wastes and waste materials are currently receiving attention as raw materials for water pollution control because of their availability and low-cost (Horsefall Jnr and Spiff, 2005).

In this context, we are investigating the potential of STD and RCP an agricultural solid waste, as alternative low-cost adsorbents for the removal of MB dye from aqueous solutions. Very few studies were reported the comparative removal of dyes using these agricultural wastes. Based on the kinetic and isotherm studies, adsorption capacities of both low cost adsorbent compared.

\section{MATERIALS AND METHODS}

\subsection{Adsorbate}

MB obtained from Merck was used for all experiments, without further purification. The MB was chosen in this study because of its known strong adsorption onto solids. The maximum absorption wavelength of this dye is $668 \mathrm{~nm}$. The structure of MB is shown in Fig. 1.

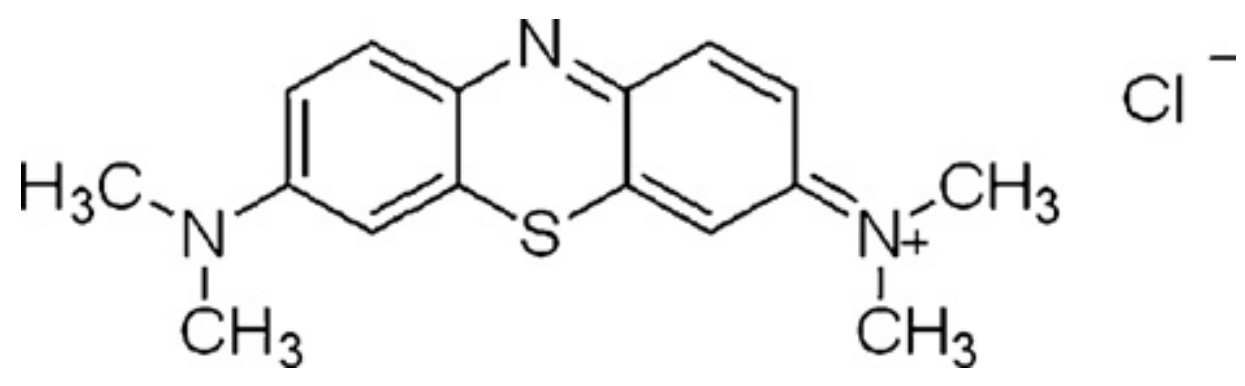

Figure 1. The Chemical Structure of MB

\subsection{Adsorbent}

STD was collected from the Opal Hostel Mess, NIT, Trichy. It was repeatedly washed with water until the filtered water was clear. It was then oven dried at $60^{\circ} \mathrm{C}$ for 48 hours. The dried sample was grounded and sieved to a particle size of 300 to 600 microns. 'Waste' coir pith was obtained from a coir industry at Omalur, Salem district, India. It was dried in sunlight for 5 hours. It was then powdered and sieved to a size of 600-300 microns. No other chemical or physical treatments were used prior to the adsorption experiment. The prepared STD and RCP is shown in Fig. 2. 


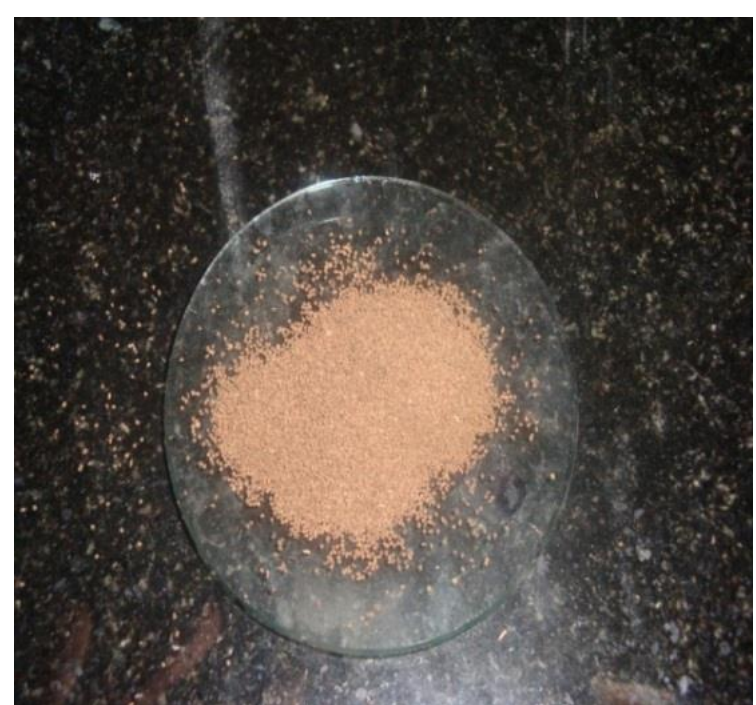

(a) Spent Tea Dust

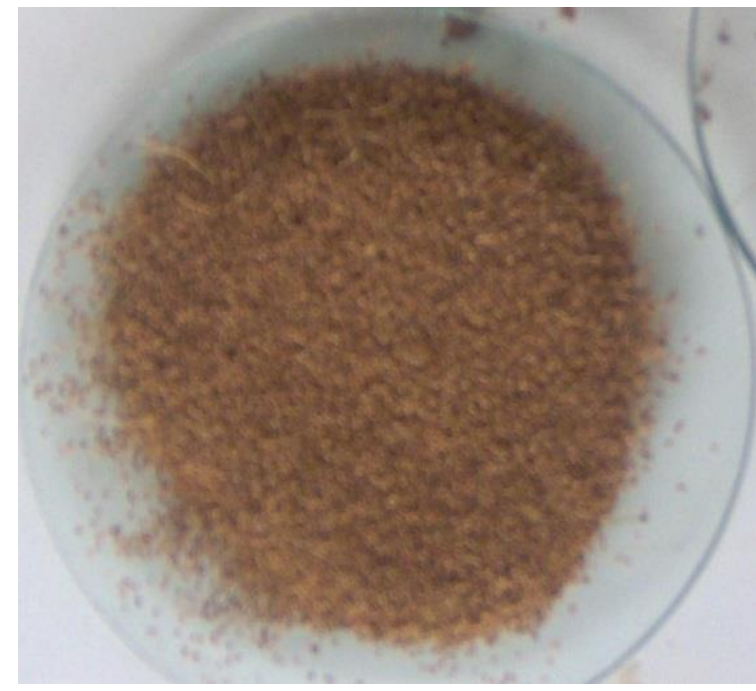

(b) Raw coir pith

Figure 2. Adsorbents used in the present study

\subsection{Effect of contact time}

Batch experiments were carried out by placing $0.35 \mathrm{~g}$ of STD and $0.1 \mathrm{~g}$ of RCP separately in $100 \mathrm{ml}$ of aqueous solution containing $25 \mathrm{mg} \mathrm{l}^{-1}$ of $\mathrm{MB}$ and then agitating the mixtures at $130 \mathrm{rpm}$ with varying contact times from 2 min to $240 \mathrm{~min}$ in a system $\mathrm{pH}$ of 7 at $27{ }^{\circ} \mathrm{C}$. The adsorbent and adsorbate were separated by centrifugation at $4500 \mathrm{rpm}$ for $10 \mathrm{~min}$. Then, the MB concentration remaining in the supernatant was measured using a UV- visible spectrophotometer (Lambda 25, PerkinElmer, USA). The amount of sorption at time $t, q\left(\mathrm{mg} \mathrm{g}^{-1}\right)$, was calculated by:

$q_{t}=\frac{\left(C_{0}-C_{t}\right) V}{W}$

where $C_{0}$ and $C_{\mathrm{t}}\left(\mathrm{mg} \mathrm{l}^{-1}\right)$ are the liquid-phase concentrations of dye at initial and any time t, respectively. $V$ is the volume of the solution (I) and $W$ is the mass of dry sorbent used $(\mathrm{g})$.

\subsection{Effect of adsorbent dosage}

The effect of the adsorbent dosage on the adsorption of MB was studied by varying the STD dosage $(0.05$ to $0.40 \mathrm{~g})$ and RCP dosage $(0.02$ to $0.24 \mathrm{~g})$ in $100 \mathrm{ml}$ of dye solution. The mixtures were agitated in shaker at $130 \mathrm{rpm}$ and $27^{\circ} \mathrm{C}$ for $180 \mathrm{~min}$ in case of STD and $60 \mathrm{~min}$ in case of RCP until equilibrium was reached. Aqueous samples were taken from the solutions and the concentrations were analyzed. At time $t=0$ and at equilibrium, the dye concentrations were measured by UV/VIS spectrophotometer at $668 \mathrm{~nm}$. The amount of equilibrium adsorption, $q_{\mathrm{e}}\left(\mathrm{mg} \mathrm{g}^{-1}\right)$, was calculated by

$\mathrm{q}_{\mathrm{t}}=\frac{\left(\mathrm{C}_{0}-\mathrm{C}_{e}\right) \mathrm{V}}{\mathrm{W}}$

where $\mathrm{C}_{0}$ and $\mathrm{C}_{\mathrm{e}}\left(\mathrm{mg} \mathrm{l}^{-1}\right)$ are the liquid-phase concentrations of dye at initial and equilibrium, respectively.

\subsection{Effect of system pH}

The effect of the system $\mathrm{pH}$ was studied, following the same procedure as for the contact time, over a system pH range from 2 to 10 adjusted with $1 \mathrm{M} \mathrm{NaOH}$ or $0.1 \mathrm{M} \mathrm{H}_{2} \mathrm{SO}_{4}$ after the addition of STD $(0.35 \mathrm{~g}$ per $100 \mathrm{ml})$ and RCP $(0.12 \mathrm{~g}$ per $100 \mathrm{ml})$. Agitation was provided for equilibrium time period with a constant agitation speed of $130 \mathrm{rpm}$. The $\mathrm{pH}$ was measured by using a pH meter (pHTestr 30, Eutech, Singapore). 


\section{RESULTS AND DISCUSSION}

\subsection{Effect of contact time}

Initial batch studies conducted to assess the time taken for the equilibrium to be attained were performed for two different types of adsorbents (STD and RCP). The influence of contact time on removal of MB by STD and RCP is shown in Fig. 3.

It is evident that both the adsorbents are efficient to adsorb MB with different efficiencies. It was observed that dye uptake is rapid for the first $15 \mathrm{~min}$ and thereafter it proceeds at a slower rate and finally attains saturation. This maybe explained by a rapid adsorption on the outer surface, followed by slower adsorption inside the pores. RCP possesses higher adsorption capacity $\left(24.95 \mathrm{mg} \mathrm{g}^{-1}\right)$ than STD $\left(7.059 \mathrm{mg} \mathrm{g}^{-1}\right.$ ) at equilibrium (Table 1). To attain equilibrium, it takes $60 \mathrm{~min}$ and $180 \mathrm{~min}$ for STD and RCP respectively. In the process of dye colour adsorption, initially dye molecule has to first encounter the boundary layer effect and then it has to diffuse from boundary layer film onto adsorbent surface and then finally it has to diffuse into the porous structure of the adsorbent. This phenomenon will take relatively long contact time (Malik, 2003).

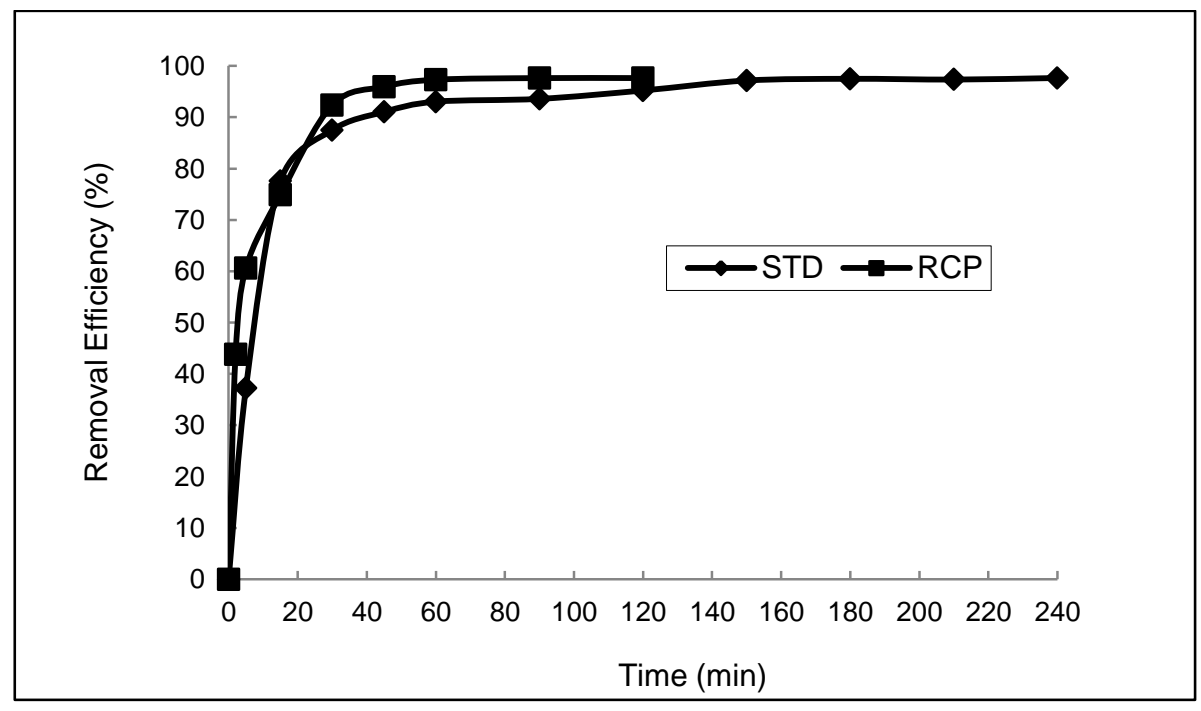

Figure 3. Effect of Contact Time on MB Adsorption by STD and RCP

\subsection{Effect of adsorbent dosage}

Fig. 4 shows the removal of MB at different adsorbent dosages $(0.05$ to $0.40 \mathrm{~g}$ of STD per $100 \mathrm{~mL}$ and, 0.02 to $0.24 \mathrm{~g}$ of RCP per $100 \mathrm{ml}$ ) at an agitation time of $60 \mathrm{~min}$ for STD and $120 \mathrm{~min}$, for RCP.

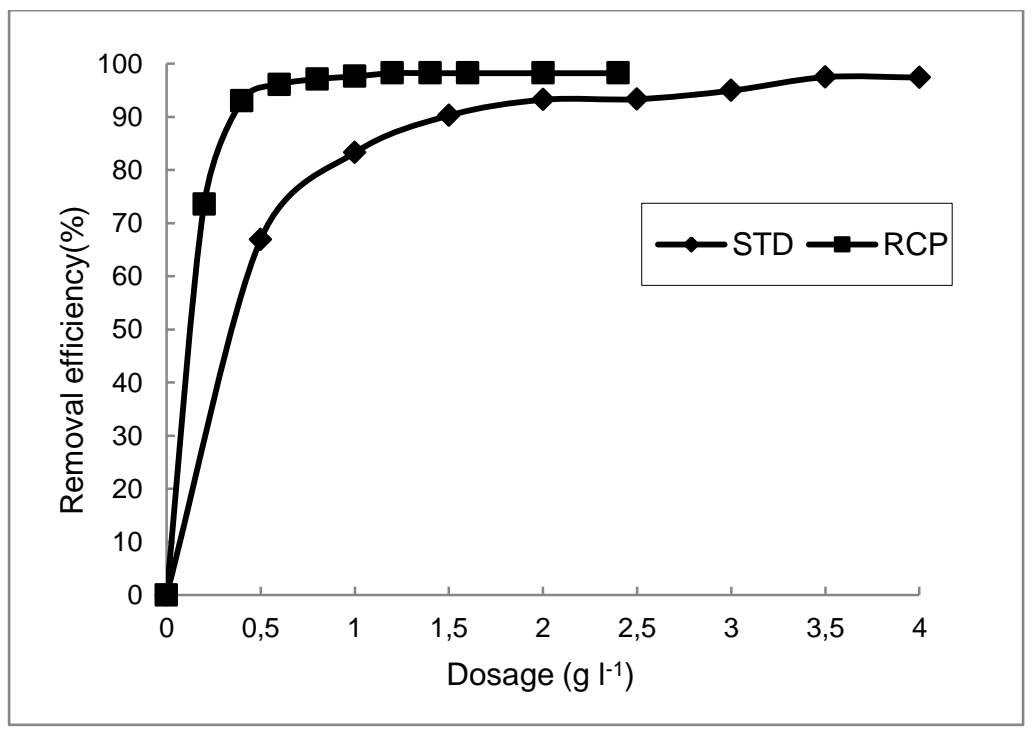

Figure 4. Effect of Dosage on MB Adsorption by STD and RCP 
The adsorption efficiency generally improved with increasing adsorbent dosage up to a certain value and then remained constant. The increase in STD dosage from 0.5 to $4.0 \mathrm{~g} \mathrm{I}^{-1}$ resulted in an increase from 66.90 to $97.49 \%$ in adsorption of MB. The increase in the adsorption percentage with increasing adsorbent dosage is due to the increase in the number of adsorbent sites (charging sites) (Selvaraj et al., 2003). The optimum dosage for MB adsorption by STD was $3.5 \mathrm{~g} \mathrm{I}^{-1}$ at $97.49 \%$ of MB adsorption. MB showed a maximum removal of $98.23 \%$ at a coir pith dose of $1.2 \mathrm{~g} \mathrm{I}^{-1}$. These results indicate that the RCP have potential adsorbent when compared to STD for MB adsorption from aqueous solution.

\subsection{Effect of system pH}

Effect of $\mathrm{pH}$ on the removal of $\mathrm{MB}$ is shown in Fig. 5. The percent removal was more than $90 \%$ in the $\mathrm{pH}$ range $4-10$ by STD and $\mathrm{RCP}$ respectively. Lower adsorption (35\%) of MB at $\mathrm{pH} 2$ by STD is due to the presence of excess $\mathrm{H}^{+}$ions competing with the dye cation for the adsorption sites. As the $\mathrm{pH}$ of the system increases, the number of positively charged sites decreases and the number of negatively charged sites increases (Kavitha and Namasivayam, 2007). At pH 2, though positively charged surface sites on the adsorbent do not favor the adsorption of dye cations due to the electrostatic repulsion, dye removal by RCP was still high (more than $80 \%$ ). As the $\mathrm{pH}$ increased, the removal increased slightly. Several investigations have reported that MB adsorption usually increases as the pH is increased (Gupta et al., 2004; Singh et al., 2003; Janos, 2003). Basically, MB and other cationic dyes produce an intense molecular cation $\left(\mathrm{C}^{+}\right)$and reduced ions $\left(\mathrm{CH}^{+}\right)$. At high $\mathrm{pH}, \mathrm{OH}^{-}$on the surface of adsorbent will favor the adsorption of cationic dye molecules (Kavitha and Namasivayam, 2007).

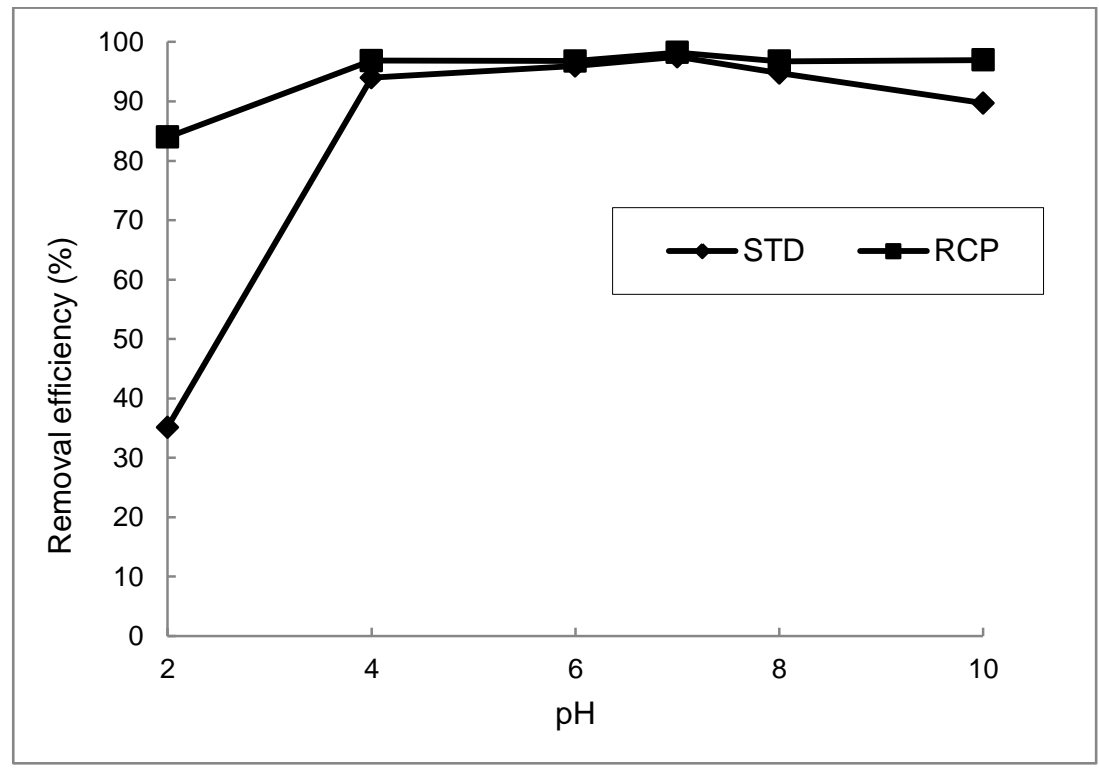

Figure 5. Effect of System pH on MB Adsorption by STD and RCP

\subsection{Adsorption kinetics}

The kinetics of MB sorption onto STD and RCP were investigated using the pseudo-first order and pseudo-second order kinetics models. The Lagergren equation (Langergren, 1898) is the most widely used rate equation in liquid phase sorption. The linearized form of the pseudo first-order equation is expressed as

$\log \left(q_{e}-q_{t}\right)=\log \left(q_{e}\right)-\frac{k_{1}}{2.303}(t)$

where, $q_{e}, q_{t}=$ the adsorption capacity at equilibrium and at time $t$, respectively $\left(\mathrm{mg} \mathrm{g}^{-1}\right)$ and $k_{1}=$ the rate constant of pseudo first-order adsorption, $\left(\mathrm{min}^{-1}\right)$. The values of $\log \left(q_{e}-q_{t}\right)$ were linearly correlated with $t$, and the plot of $\log \left(q_{e}-q_{t}\right)$ vs $t$ would result in a linear relationship from which $k_{1}$ and $\mathrm{q}_{\mathrm{e}}$ could be determined from the slope and intercept of the plot, respectively.

The pseudo second-order adsorption kinetic rate equation is given below (Ho and McKay, 1999); 


$$
\left(\frac{t}{q_{t}}\right)=\frac{1}{k_{2} q_{e}^{2}}+\frac{1}{q_{e}}(t)
$$

where $\mathrm{k}_{2}\left(\mathrm{~g} \mathrm{mg}^{-1} \mathrm{~min}^{-1}\right)$ is the rate constant of pseudo-second order adsorption reaction. The plot of $\frac{t}{q_{t}}$ and $t$ of Eq. 4 would result in a linear relationship from which $q_{e}$ and $k_{2}$ could be determined from the slope and intercept of the plot, respectively.

In order to distinguish the film diffusion or intraparticle diffusion process, the Weber-Morris (1963) equation was tested in the following form:

$\mathrm{R}=\mathrm{K}_{\mathrm{id}}(\mathrm{t})^{\mathrm{a}}$

A linearized form of this equation is given by

$$
\log \mathrm{R}=\log \mathrm{K}_{\mathrm{id}}+\operatorname{alog}(\mathrm{t})
$$

where

$\begin{array}{lll}\mathrm{R} & = & \text { the percent } \mathrm{MB} \text { adsorbed } \\ \mathrm{t} & = & \text { the contact time, } \min \\ \mathrm{a} & = & \text { the gradient of linear plots } \\ \mathrm{K}_{\mathrm{id}} & = & \text { the intraparticle diffusion rate constant, } \text { min }^{-1}\end{array}$

$\mathrm{K}_{\text {id }}$ may be taken as a rate factor, i.e., percent MB adsorbed per unit time. The plot of log $(\mathrm{R})$ and $\log (\mathrm{t})$ of Eq. 6 would result in a linear relationship from which $a$ and $K_{\text {id }}$ could be determined from the slope and intercept of the plot, respectively.

Figs. 6-8 show the plot of the first-order, second-order and intraparticle diffusion models for adsorption of MB by the STD and RCP respectively.

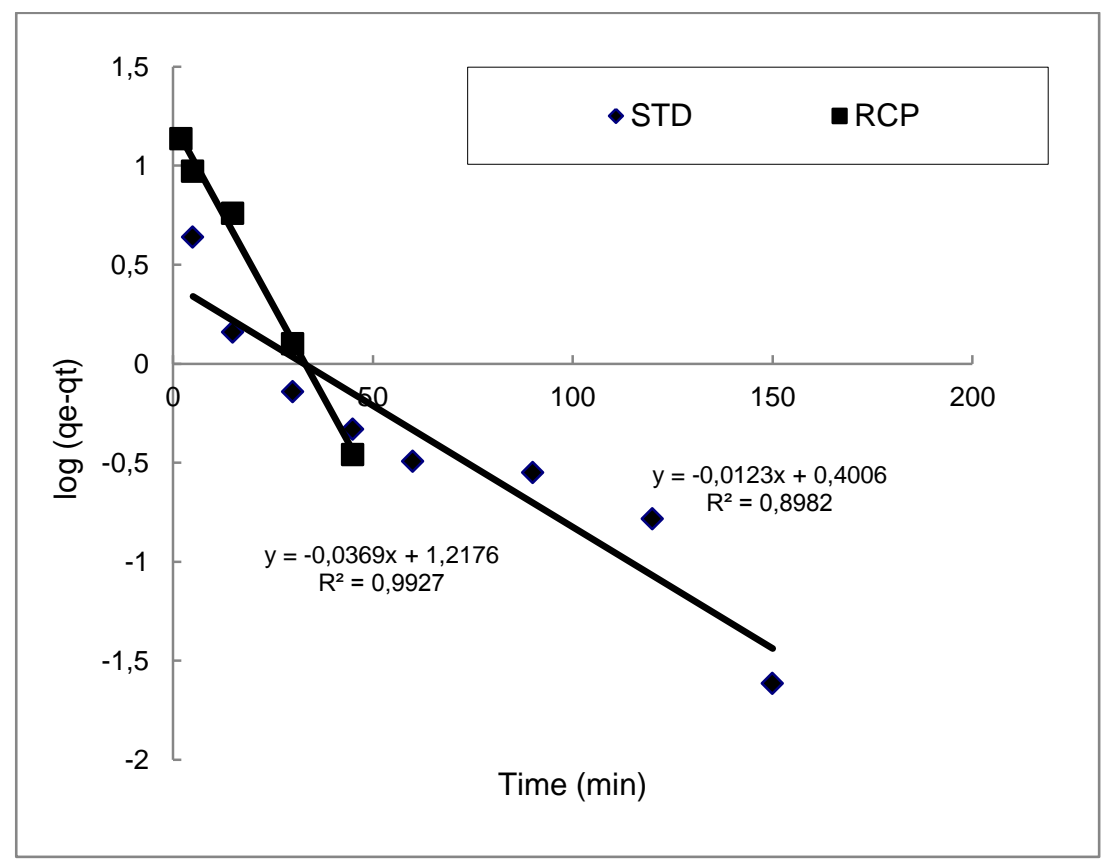

Figure 6. Pseudo First order kinetics plot for the removal of methylene blue 


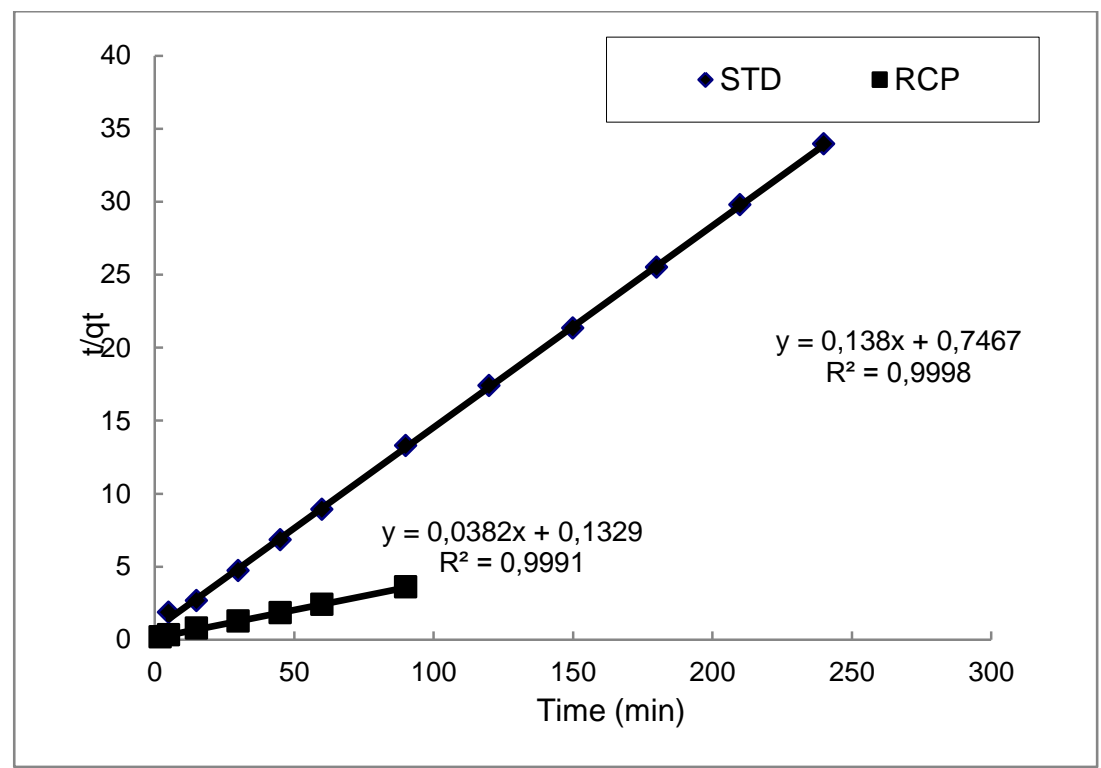

Figure 7. Pseudo Second-order kinetics plot for the removal of methylene blue

Experimental and theoretically calculated $q_{\mathrm{e}}$ values and coefficients related to kinetic plots are listed in Table 1. The theoretical $q_{\mathrm{e}}$ values for the adsorbents were very close and significantly different to the experimental $q_{\mathrm{e}}$ values in the case of second and first-order kinetic models, respectively (Table 1). Therefore the second-order kinetics best describe the data well than that of pseudo first order model. Higher values of the intraparticle diffusion rate constant ' $K_{\text {id }}$ ' illustrate an enhancement in the rate of adsorption, whereas larger values of the gradient of linear plots ( $\alpha$ ) illustrate a better adsorption mechanism (Kobya, 2004). The values of ' $\alpha$ ' for MB by STD and RCP were 0.196 and 0.199 respectively. The value of ' $\alpha$ ' being less than 0.50 indicates that the intraparticle diffusion is not a rate determining step (Kobya, 2004).

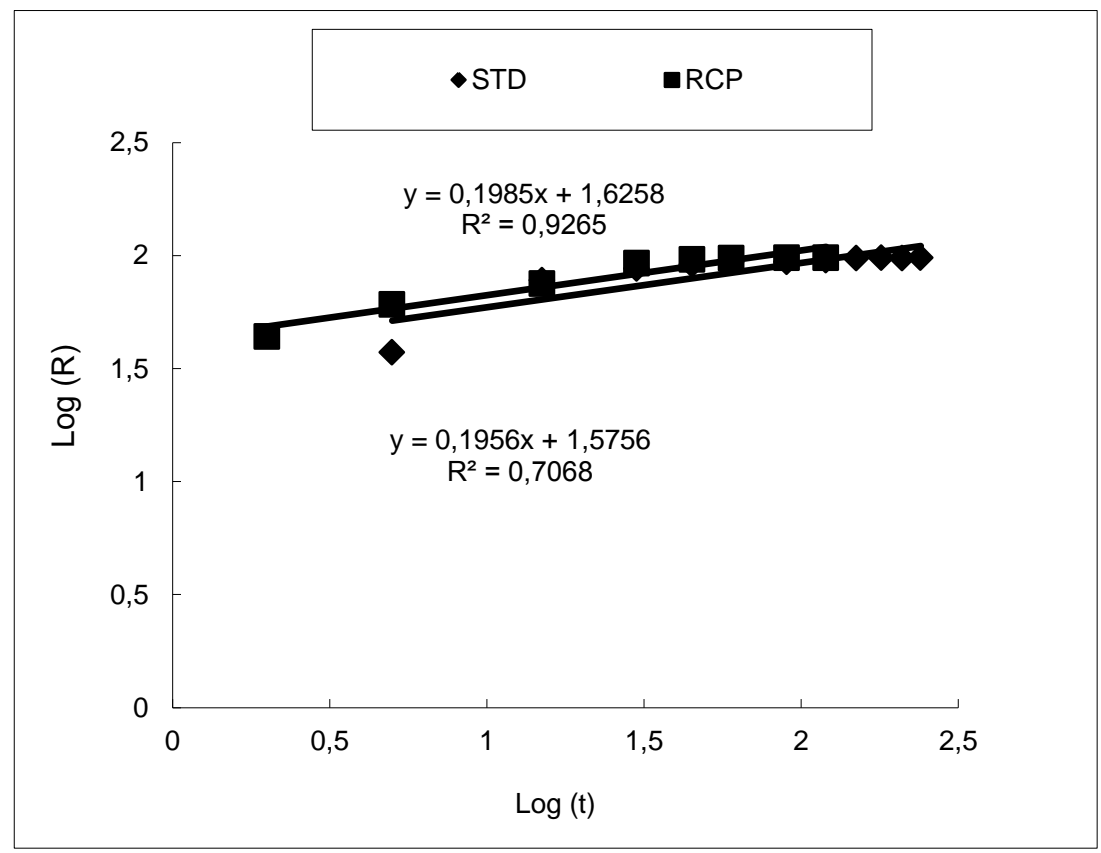

Figure 8. Intraparticle diffusion plot for the removal of MB by STD and RCP 
Table 1. Adsorption Kinetic Model Rate Constants

\begin{tabular}{|c|c|c|c|}
\hline \multicolumn{2}{|c|}{ ADSORBENT } & STD & RCP \\
\hline \multicolumn{2}{|c|}{$q_{e}(\exp )\left(\mathrm{mg} \mathrm{g}^{-1}\right)$} & 7.059 & 24.95 \\
\hline \multirow{3}{*}{ PSEUDO-FIRST ORDER } & $\begin{array}{c}q_{e} \\
\text { (cal) }\left(\mathrm{mg} \mathrm{g}^{-1}\right)\end{array}$ & 2.515 & 16.50 \\
\hline & $\begin{array}{l}\text { Rate constant } k_{1} \\
\left(\min ^{-1}\right)\end{array}$ & 0.0283 & 0.0849 \\
\hline & $\mathbf{R}^{2}$ & 0.8982 & 0.9927 \\
\hline \multirow{3}{*}{ PSEUDO-SECOND ORDER } & $\mathrm{q}_{\mathrm{e}}(\mathrm{cal})\left(\mathrm{mg} \mathrm{g}^{-1}\right)$ & 7.246 & 26.18 \\
\hline & $\begin{array}{l}\text { Rate constant } k_{2} \\
\left(\mathrm{~g} \mathrm{mg} \mathrm{m}^{-1} \mathrm{~min}^{-1}\right)\end{array}$ & 0.0255 & 0.0109 \\
\hline & $\mathbf{R}^{2}$ & 0.9998 & 0.9991 \\
\hline \multirow{3}{*}{$\begin{array}{l}\text { INTRAPARTICLE DIFFUSION } \\
\text { MODEL }\end{array}$} & $\begin{array}{l}\mathrm{K}_{\text {id }} \text { Percent } \\
\text { min }^{-1}\end{array}$ & 37.64 & 42.24 \\
\hline & $\alpha$ & 0.196 & 0.199 \\
\hline & $\mathbf{R}^{2}$ & 0.7068 & 0.9265 \\
\hline
\end{tabular}

\subsection{Equilibrium isotherms}

Two isotherms were tested for their ability to describe the experimental results, namely the Langmuir isotherm and the Freundlich isotherm. The thermodynamic assumptions of the best fitting isotherm provide insight into both the surface properties and the mechanism of adsorption. The derivation of the Langmuir isotherm is based on the assumption of ideal monolayer adsorption on a homogenous surface. It is expressed by:

$q_{e}=\frac{q_{m} b C_{e}}{1+b C_{e}}$

where $C_{e}$ is the equilibrium concentration $\left(\mathrm{mg} \mathrm{l}^{-1}\right), \mathrm{q}_{\mathrm{e}}$ the amount of dye adsorbed at equilibrium $\left(\mathrm{mg} \mathrm{g}^{-1}\right), \mathrm{q}_{\mathrm{m}}$ is $\mathrm{q}_{\mathrm{e}}$ for complete monolayer adsorption capacity $\left(\mathrm{mg} \mathrm{g}^{-1}\right)$, and $\mathrm{b}$ is the equilibrium adsorption constant $\left(\mathrm{I} \mathrm{mg}^{-1}\right)$.

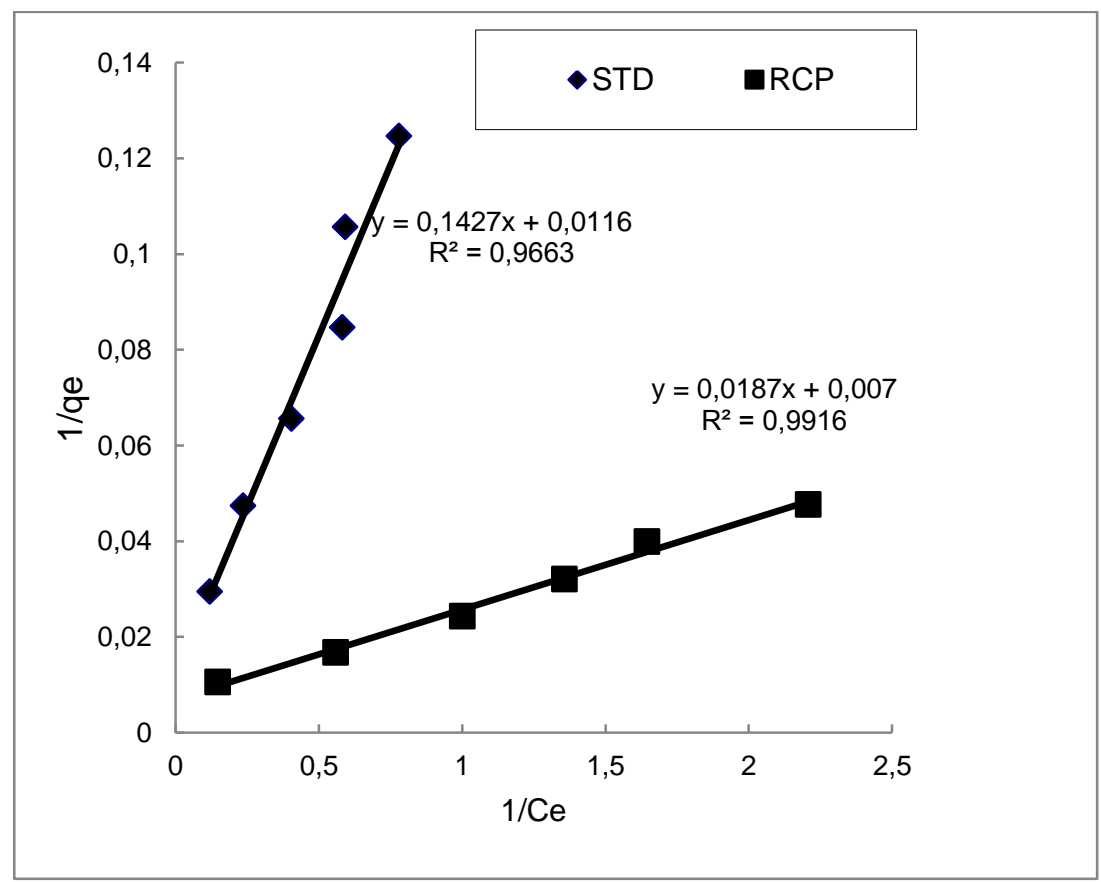

Figure 9. Langmuir isotherm for the adsorption of MB on STD and RCP

The Freundlich isotherm is used for non-ideal adsorption on heterogeneous surfaces. The heterogeneity is caused by the presence of different functional groups on the surface, and also by 
various mechanisms of adsorbent-adsorbate interactions. The Freundlich isotherm is represented by the following empirical equation:

$\mathrm{q}_{\mathrm{e}}=\mathrm{K}_{\mathrm{F}} \mathrm{C}_{\mathrm{e}}^{1 / \mathrm{n}}$

where $K_{\mathrm{F}}$ is the Freundlich adsorption constant and $n^{-1}$ is a measure of the adsorption intensity.

Fig. 9 and 10 shows the fitted equilibrium data to Langmuir and Freundlich, expressions. The fitting results, i.e. isotherm parameters and the coefficients of determination, $R^{2}$, are shown in Table 2 . It can be seen in Fig. 9 that the Langmuir plot is a better fit of the experimental data compared to Freundlich plot (Fig.10) for both the adsorbents. The MB adsorption capacity on RCP was 142.86 $\mathrm{mg} \mathrm{g}^{-1}$ at $27^{\circ} \mathrm{C}$, whereas that of STD was only $86.21 \mathrm{mg} \mathrm{g}^{-1}$ adsorbent under the same conditions. The magnitude of the exponent ' $n$ ' gives an indication of the favourability and $K_{F}$ the capacity of the adsorbent / adsorbate system. The ' $n$ ' values (1.17 for STD and 1.57 for RCP) between 1 and 10 indicate beneficial adsorption (Asfour et al., 1985).

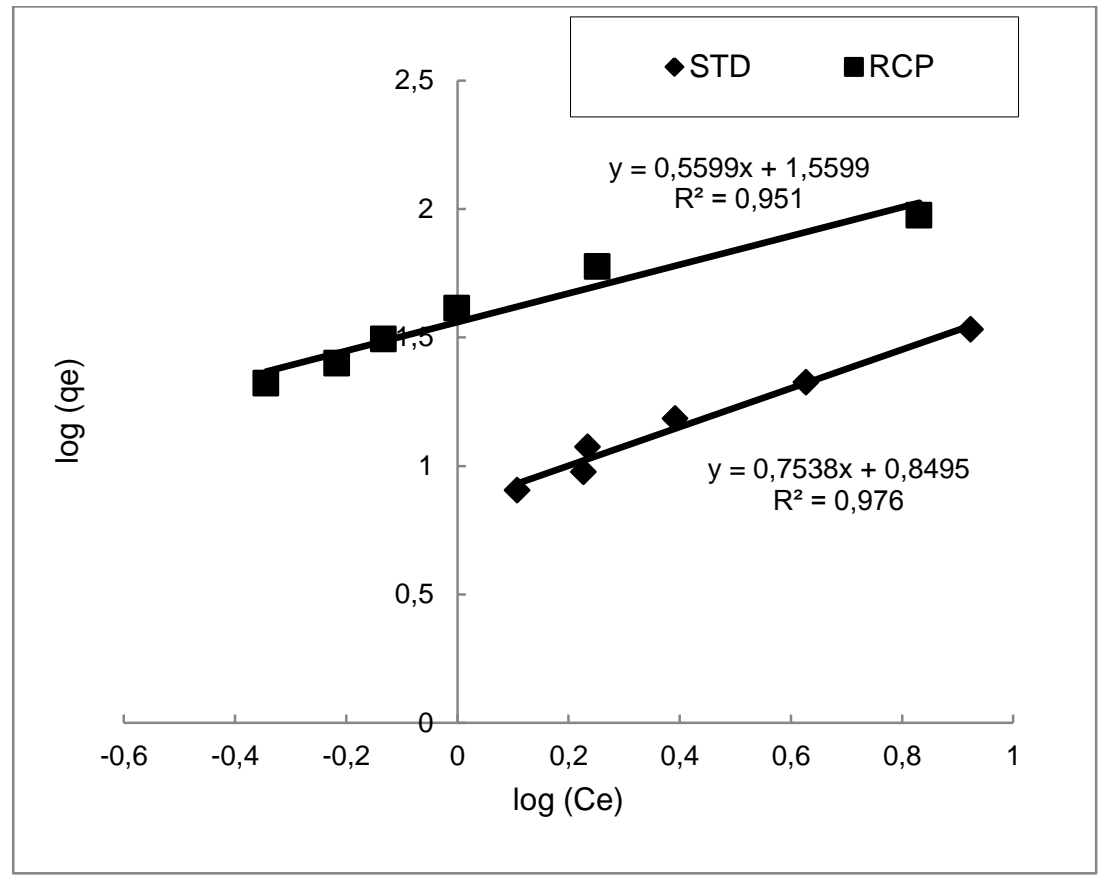

Figure 10. Freundlich isotherm for the adsorption of MB on STD and RCP

Table 2. Isotherm Parameters for Removal of MB by STD and raw coir pith

\begin{tabular}{cccccccc}
\hline Adsorbent & \multicolumn{3}{c}{ Langmuir Isotherm Constants } & \multicolumn{3}{c}{ Freundlich Isotherm Constants } \\
\cline { 2 - 8 } & $\mathbf{q}_{\mathbf{m}}\left(\mathbf{m g ~ g}^{-1}\right)$ & $\mathbf{b}\left(\mathbf{L ~ m g ~}^{-1}\right)$ & $\mathbf{R}^{2}$ & $\mathbf{R}_{\mathbf{L}}$ & $\mathbf{K}_{\mathbf{F}}\left(\mathbf{m g ~ g}^{-1}\right)$ & $\mathbf{n}$ & $\mathbf{R}^{\mathbf{2}}$ \\
\hline STD & 86.21 & 0.0812 & 0.9663 & 0.32 & 5.67 & 1.17 & 0.976 \\
\hline RCP & 142.86 & 0.374 & 0.9916 & 0.09 & 36.29 & 1.56 & 0.951 \\
\hline
\end{tabular}

The essential characteristics of Langmuir isotherm can be expressed by a dimensionless constant called equilibrium parameter $\mathrm{R}_{\mathrm{L}}$, defined by Weber and Chakkravorti (1974):

$\mathrm{R}_{\mathrm{L}}=\frac{1}{1+\mathrm{bC}_{0}}$

where $b$ is the Langmuir constant and $C_{0}$ is the initial dye concentration ( $\left.\mathrm{mg} \mathrm{I}^{-1}\right), R_{L}$ values indicate the type of isotherm. Table 2 shows $R_{L}$ values between zero and one, which indicate favorable adsorption (Kavitha and Namasivayam, 2007). 
The adsorption capacities various adsorbents used for MB removal were compared with present study and given in Table 3. From the Table 3, it is very clear that the capacities of adsorbents for adsorbing MB are in a wide range. It is vary from 3.745 to $472.10 \mathrm{mg} \mathrm{g}^{-1}$. The adsorption capacities of RCP and STD are very less compared to straw carbon, rice husk carbon, wheat straw, rice husk etc. But the MB adsorption capacity of RCP is comparable with groundnut shell carbon, hair, garlic peel and bamboo dust carbon. Similarly the adsorption capacity of STD is very similar to that of raw date pits and hazelnut shell.

Table 3. Adsorption capacities of various adsorbents for the removal of MB

\begin{tabular}{clcc}
\hline No & \multicolumn{1}{c}{ Adsorbent } & $\mathbf{q}_{\mathbf{m}}\left(\mathbf{m g ~ g}^{-1}\right)$ & Reference \\
\hline 1 & Straw carbon & 472.10 & Kannan and Sundaram (2001) \\
\hline 2 & Rice husk carbon & 343.50 & Kannan and Sundaram (2001) \\
\hline 3 & Wheat straw & 312.50 & Gong et al. (2008) \\
\hline 4 & Rice husk & 312.00 & McKay et al. (1999) \\
\hline 5 & Spent tea leaves & 300.052 & Hameed (2009 a) \\
\hline 6 & Jack fruit peel & 285.713 & Hameed (2009 b) \\
\hline 7 & Coconut shell carbon & 277.90 & Kannan and Sundaram (2001) \\
\hline 8 & Cotton waste & 270.00 & McKay et al. (1999) \\
\hline 9 & Coal & 250.00 & McKay et al. (1999) \\
\hline 10 & Coconut tree sawdust carbon & 225.50 & Kadirvelu et al. (2003) \\
\hline 11 & Diatomite & 198 & Al-Ghouti et al. (2003) \\
\hline 12 & Groundnut shell carbon & 164.90 & Kannan and Sundaram (2001) \\
\hline 13 & Hair & 158.00 & McKay et al. (1999) \\
\hline 14 & Bamboo dust carbon & 143.20 & Kannan and Sundaram (2001) \\
\hline 15 & RCP & 142.86 & Present Study \\
\hline 16 & Garlic peel & 142.86 & Hameed and Ahmad (2009) \\
\hline 17 & Silk cotton carbon & 120.00 & Kadirvelu et al. (2003) \\
\hline 18 & STD & 86.21 & Present Study \\
\hline 19 & Raw date pits & 80.29 & Banat et al. (2003) \\
\hline 20 & Hazelnut shell & 76.9 & Ferrero (2007) \\
\hline 21 & Banana peel & 37.7 & Annadurai et al. (2002) \\
\hline 22 & Sugarcane bagasse & 34.20 & Filho et al. (2007) \\
\hline 23 & Banana pith & 20.80 & Annadurai et al. (2002) \\
\hline 24 & Orange peel & 18.60 & Annadurai et al. (2002) \\
\hline 25 & Sugarcane dust & 3.745 & Khattri and Singh (1999) \\
\hline & & & \\
\hline
\end{tabular}

\subsection{Fourier transform infrared (FTIR) analysis}

The functional groups on the surface of the STD and RCP before and after adsorption of MB were analyzed by a FTIR spectrophotometer (FTIR-2000, Perkin Elmer) where the spectra were recorded from 4000 to $500 \mathrm{~cm}^{-1}$ (Fig. 11).

From the figure, it was found that both adsorbents have peaks at $3417,2923,1634,1518,1451$, $1383,1239,1148$ and $1049 \mathrm{~cm}^{-1}$. The broad peak at $3417 \mathrm{~cm}^{-1}$ attributed to the $\mathrm{O}-\mathrm{H}$ stretching on the adsorbent surface (Ramesh et al., 2011). The stretching vibration of $\mathrm{C}-\mathrm{H}$ group was observed at $2923 \mathrm{~cm}^{-1}$ (Nidheesh et al., 2012). The presence of COO, N-H and C-O groups on the adsorbent surface was indicated by the peaks at 1634,1518 and $1451 \mathrm{~cm}^{-1}$ respectively (Kumar and Ahmad, 2011). The peaks of methoxy groups $\left(\mathrm{O}-\mathrm{CH}_{3}, 1451 \mathrm{~cm}^{-1}\right), \mathrm{O}-\mathrm{H}$ deformation originating from the 
phenolic group $\left(1383 \mathrm{~cm}^{-1}\right), \mathrm{C}-\mathrm{OH}$ stretching in primary alcohol $\left(1049 \mathrm{~cm}^{-1}\right)$ and secondary alcohol $\left(1148 \mathrm{~cm}^{-1}\right)$ were also observed for both the adsorbents (Ramesh et al., 2011). After the sorption of $\mathrm{MB}$, the transmittance of the peaks at 3417 and $1451 \mathrm{~cm}^{-1}$ reduced. This indicates that methoxy and hydroxyl groups were involved in the sorption of $\mathrm{MB}$ on both sorbents. In addition to this, the transmittance at $1049 \mathrm{~cm}^{-1}$ decreased in the case of RCP.

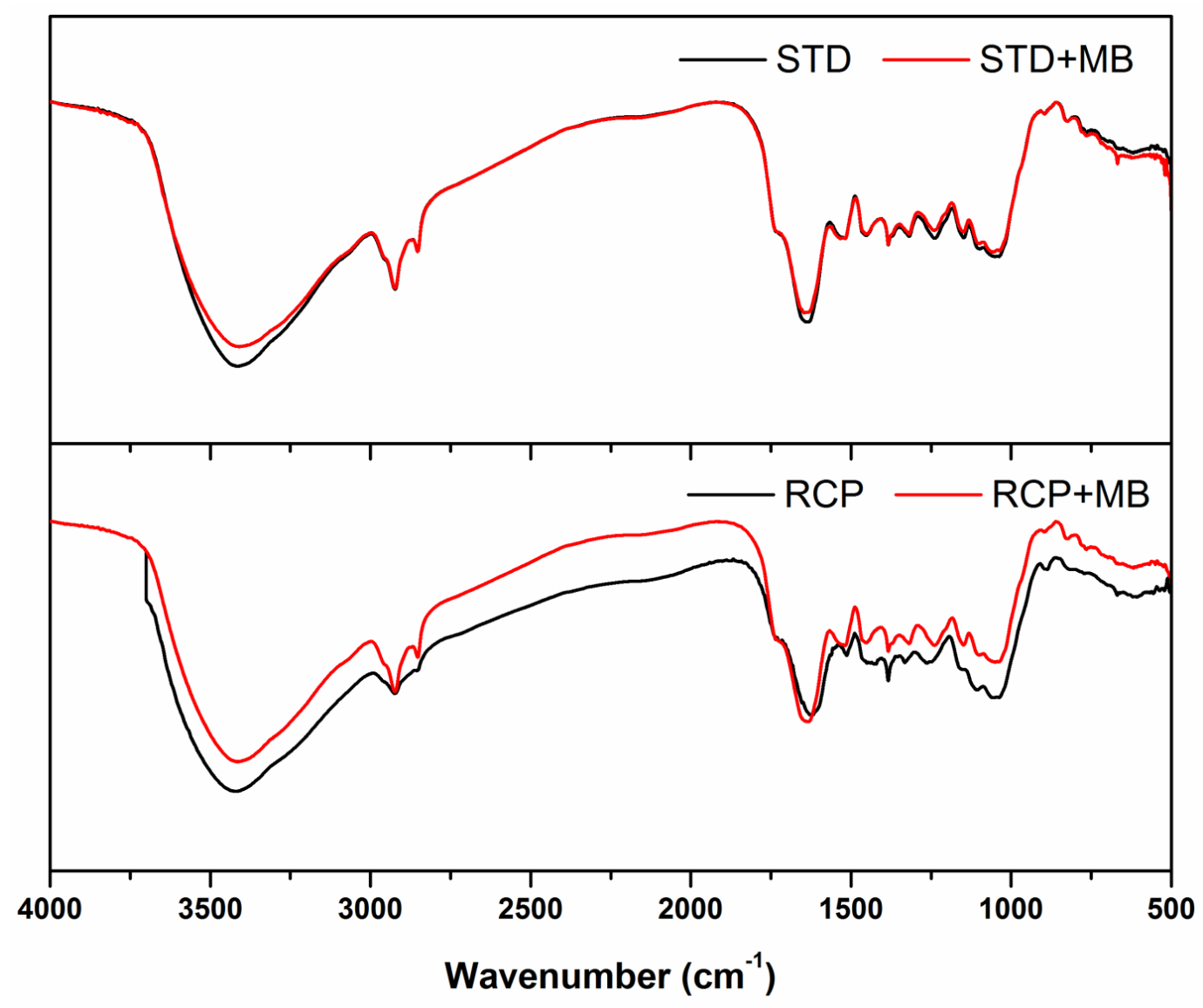

Figure 11. FTIR spectra of STD and RCP before and after sorption of MB

\section{CONCLUSIONS}

The results of present investigation show that the low cost adsorbent materials, STD and RCP have suitable adsorption capacity with regard to the removal of MB from its aqueous solution. RCP has better adsorption capacity than spent tea dust. The adsorption is highly dependent on contact time, adsorbent dose and pH. Equilibrium adsorption was achieved in about $180 \mathrm{~min}$ with STD and $60 \mathrm{~min}$ with RCP. Kinetics data tended to fit well in second-order kinetics, confirming the chemisorption of MB onto STD and RCP particles. Second order kinetics model agreed well with the $\mathrm{q}_{\mathrm{e}}$ experimental values, supporting the chemisorption. The Langmuir isotherms best represent the equilibrium adsorption data. The optimal $\mathrm{pH}$ for favorable adsorption of $\mathrm{MB}$ is 7 by both the adsorbents. It is feasible to utilize STD as a low-cost adsorbent for removing MB dye from the industrial dying wastewater. As the raw material, the coir pith is discarded as waste in coir industries; the treatment method using RCP is expected to be economical. The cost and adsorption characteristics favor RCP to be used as an effective adsorbent for the removal of MB from wastewater.

\section{REFERENCES}

Al-Ghouti M.A., Khraisheh M.A.M., Allen S.J. and Ahmad M.N. (2003), The removal of dyes from textile wastewater: A study of the physical characteristics and adsorption mechanisms of diatomaceous earth, Journal of Environmental Management, 69, 229- 238.

Annadurai G., Juang R.S. and Lee D.J. (2002), Use of cellulose based wastes for adsorption of dyes from aqueous solutions, Journal of Hazardous Materials, 92, 263-274. 
Asfour H.M., Fadali O.A., Nassar M.M. and El-Geundi M.S. (1985), Equilibrium Studies on Adsorption of Basic Dyes on Hard Wood, J. Chem. Tech. Biotechnol., 35A, 21-27.

Banat F., Al-Asheh S. and Al-Makhadmeh L. (2003), Evaluation of the use of raw and activated date pits as potential adsorbents for dye containing waters, Process Biochemistry, 39, 193-202.

Banat M., Nigam P., Singh D. and Marchant R. (1996), Microbial decolorization of textile-dyecontaining effluents: A review, Bioresource Technology, 58, 217-227.

Ellouze E., Ellouze D., Jrad A. and Ben Amar R. (2011), Treatment of synthetic textile wastewater by combined chemical coagulation/membrane processes, Desalination and Water Treatment, 33, 118-124.

Eren Z. and Acar F.N. (2006), Adsorption of Reactive Black 5 from an aqueous solution: equilibrium and kinetic studies, Desalination, 194, 1-10.

Ferrero F. (2007), Dye removal by low cost adsorbent: Hazelnut shells in comparison with wood sawdust, Journal of Hazardous Materials, 142, 144-152.

Feryal A. (2005), Adsorption of basic dyes from aqueous solution onto pumice powder, J. Colloid Interface Sci., 286, 455-458.

Filho N.C., Venancio E.C., Barriquello M.F., Hechenleitner A.A. and Pineda E.A.G. (2007), Methylene blue adsorption onto modified lignin from sugarcane bagasse, Eclética Química, 32, 63-70.

Forgacs E., Cserháti T. and Oros G. (2004), Removal of synthetic dyes from wastewaters: a review, Environ. Int., 30, 953-971.

Gandhimathi R., Ramesh S.T., Sindhu V. and Nidheesh P.V. (2012) Single and Tertiary System Dye Removal from Aqueous Solution Using Bottom Ash: Kinetic and Isotherm Studies, Iranica Journal of Energy \& Environment, 3(1), 52-62.

Gong R., Zhu S., Zhanga D., Chen J., Ni S. and Guan R. (2008), Adsorption behavior of cationic dyes on citric acid esterifying wheat straw: kinetic and thermodynamic profile, Desalination, 230, 220-228.

Gupta V.K., Suhas A.I. and Saini V.K. (2004), Removal of rhodamine B, fast green and methylene blue from wastewater using red mud, an aluminum industry waste, Ind. Eng. Chem. Res., 43, 1740-1747.

Hamdaoui O. and Chiha M. (2007), Removal of methylene blue from aqueous solutions by wheat bran, Acta Chim. Slov., 54, 407-418.

Hameed B.H. (2009 a), Spent tea leaves: a new non-conventional and low-cost adsorbent for removal of basic dye from aqueous solutions, Journal of Hazardous Materials, 161, 753-759.

Hameed B.H. (2009 b), Removal of cationic dye from aqueous solution using jackfruit peel as nonconventional low-cost adsorbent, Journal of Hazardous Materials, 162, 344-350.

Hameed B.H. and Ahmad A.A. (2009), Batch adsorption of methylene blue from aqueous solution by garlic peel, an agricultural waste biomass, Journal of Hazardous Materials, 164, 870-875.

Hameed B.H. and El-Khaiary M.I. (2008), Removal of basic dye from aqueous medium using noval agricultural waste material: Pumpkin seed hull, Journal of Hazardous Materials, 155, 601-609.

Ho Y.S. and McKay G. (1999), Pseudo-second order model for sorption processes, Process Biochemistry, 34, 451-465.

Horsefall Jnr M. and Spiff A.I. (2005), Effect of 2-mercaptoethanoic acid treatment of fluted pumpkin waste (Telfairia occidentalis Hook. F.) on the sorption of $\mathrm{Ni}^{2+}$ ions from the aqueous solution, Journal of scientific and industrial research, 64, 613-620.

Janos P. (2003), Sorption of basic dyes onto iron humate, Environ. Sci.Technol., 37, 5792-5798.

Kadirvelu K., Kavipriya M., Karthika C., Radhika M., Vennilamani N. and Pattabhi S. (2003), Utilization of various agricultural wastes for activated carbon preparation and application for the removal of dyes and metal ions from aqueous solutions, Bioresource Technology, 87, 129-132.

Kannan N. and Sundaram M.M. (2001), Kinetics and mechanism of removal of methylene blue by adsorption on various carbons-A comparative study, Dyes and Pigments, 51, 25-40.

Kavitha D. and Namasivayam C. (2007), Experimental and kinetic studies on methylene blue adsorption by coir pith carbon, Bioresource Technology, 98, 14-21. 
Khataee A.R. and Zarei M. (2011), Photoelectrocatalytic decolorization of diazo dye by zinc oxide nanophotocatalyst and carbon nanotube based cathode: Determination of the degradation products, Desalination, 278, 117-125.

Khattri S.D. and Singh M.K. (1999), Colour removal from dye wastewater using sugar cane dust as an adsorbent, Adsorpt. Sci. Technol., 17, 269-282.

Kobya M. (2004), Removal of $\mathrm{Cr}(\mathrm{VI})$ from aqueous solutions by adsorption onto hazelnut shell activated carbon: kinetic and equilibrium studies, Bioresour. Technol., 91, 317-321.

Kumar, R. and Ahmad, R. (2011), Biosorption of Hazardous Crystal Violet Dye from Aqueous Solution onto Treated Ginger Waste (TGW), Desalination, 265(2), 112-118.

Langergren S. (1898), About the theory of so-called adsorption of soluble substances, Kungliga Svenska Vetenskapsakademies Handlingar, 24(4), 1-39.

Lodha S., Jain A. and Punjabi P.B. (2011), A novel route for waste water treatment: Photocatalytic degradation of rhodamine B, Arabian Journal of Chemistry, 4, 383-387.

Malik P.K. (2003), Use of activated carbons prepared from sawdust and rice husk for adsorption of acid dyes: a case study of Acid Yellow 36, Dyes and Pigments, 56, 239-249.

McKay G., Porter J.F. and Prasad G.R. (1999), The removal of dye colors from aqueous solutions by adsorption on low-cost materials, Water, Air, and Soil Pollution, 114, 423-438.

Mokgalaka N.S., McCrindle R.I. and Botha B.M. (2004), Multielement analysis of tea leaves by inductively coupled plasma optical emission spectrometry using slurry nebulisation, J. Anal. Atomic Spectrom. 19, $1375-1378$.

Namasivayam C., Dinesh Kumar M., Selvi K., Begum Ashruffunissa R., Vanathi T. and Yamuna R.T. (2001), Waste coir pith a potential biomass for the treatment of dyeing wastewaters, Biomass Bioenergy, 21, 477-483.

Nidheesh P.V., Gandhimathi R. and Ramesh S.T. (2013), Degradation of dyes from aqueous solution by Fenton processes: A review, Environmental Science and Pollution Research., 20, 2099-2132.

Nidheesh P.V., Gandhimathi R., Ramesh S.T. and Anantha Singh T. S. (2012), Adsorption and desorption characteristics of crystal violet in bottom ash column, J. Urban Environ. Eng., 6, 18-29.

Nidheesh P.V., Gandhimathi R., Ramesh S.T. and Anantha Singh T.S. (2011), Investigation of Equilibrium and Thermodynamic parameters of Crystal Violet Adsorption onto Bottom Ash, J. Int. Environmental Application \& Science, 6(4), 461-470.

O'Neill C., Hawkes F.R., Lourenco N.D., Pinheiro H.M. and Delee W. (1999), Color in textile effluentssource, measurement, discharge contents and simulation: a review. J Chem Technol Biotechnol, 74, 1009-1018.

Pearce C.I., Lloyd J.R. and Guthrie J.T. (2003), The removal of colour from textile wastewater using whole bacterial cells: a review, Dyes and Pigments, 58, 179-196.

Rajabi M., Bagheri Roochi M. and Asghari A. (2011), Effect of Electrolyte Nature on Kinetics of Remazol Yellow G Removal by Electrocoagulation, Russian Journal of Physical Chemistry A, 85, 1820-1824.

Ramesh S.T., Gandhimathi R., Badabhagni N. and Nidheesh P.V. (2011), Removal of Cd (II) from aqueous solution by adsorption onto coir pith, an agricultural solid waste: batch experimental study, Environ. Eng. Manage. J., 10, 1667-1673.

Renmin G., Yingzhi S., Jian C., Huijun L. and Chao Y. (2005), Effect of chemical modification on dye adsorption capacity of peanut hull, Dyes Pig., 67, 175-181.

Robinson T., McMullan G., Marchant R. and Nigam P. (2001), Remediation of dyes in textile effluent: a critical review on current treatment technologies with a proposed alternative, Bioresource Technology, 77, 247-255.

Sampa C. and Binay K.D. (2005), On the adsorption and diffusion of methylene blue in glass fibers, $J$. Colloid Interface Sci., 286, 807-811.

Sevaraj K., Manonmami S. and Pattabhi S. (2003), Removal of hexavalent chromium using distillery sludge, Bioresource Technology, 89, 207-211. 
Shaobin W., Zhua Z.H., Anthony C., Haghseresht F. and Luc G.Q. (2005), The physical and surface chemical characteristics of activated carbons and the adsorption of methylene blue from wastewater, J. Colloid Interface Sci., 284, 440-446.

Singh K. P., Mohan D., Sinha S., Tondon G.S. and Gosh D. (2003), Color Removal from wastewater using low cost activated carbon derived from agricultural waste material, Ind. Eng. Chem. Res., 42, 1965-1976.

Srivastava H.P., Arthanareeswaran G., Anantharaman N. and Starov V.M. (2011), Performance of modified poly(vinylidene fluoride) membrane for textile wastewater ultrafiltration, Desalination, 282, 87-94.

Tsai W.T., Hsu H.C., Su T.Y., Lin K.Y. and Lin C.M. (2008), Removal of basic dye (methylene blue) from wastewaters utilizing beer brewery waste, Journal of Hazardous Materials, 154, 73-78.

Vadivelan V. and Vasanth Kumar K. (2005), Equilibrium, Kinetics, Mechanism and Process Design for the Sorption of Methylene Blue onto Rice Husk, J. Colloid Interface Sci., 286, 90-100.

Weber Jr. W.J., Morris J.C. (1963), Kinetics of adsorption on carbon from solution, J. Sanitary Eng. Div. Proceed. Am. Soc. Civil Eng., 89, 31-60.

Weber T.W. and Chakkravorti P. (1974), Pore and solid diffusion models for fixed-bed adsorbers, AIChE J, 20,228-232.

Wu F.C., Tseng R.L. and Hu C.C. (2005), Comparisons of pore properties and adsorption performance of $\mathrm{KOH}$-activated and steam-activated carbons, Microporous Mesoporous Mater., 80, 95-106.

Zareyee D., Tayebi H. and Javadi S.H. (2012), Preparation of polyaniline/activated carbon composite for removal of reactive red 198 from aqueous solution, Iranian Journal of Organic Chemistry, 4(1), 799802. 